\title{
Identifikasi keragaman jenis parasit cacing pada ternak ayam kampung di Kabupaten Jember
}

\section{The identification of diversity helminth parasites on local chickens in Jember Regency}

\author{
Satria Budi Kusuma ${ }^{1 *}$, Suluh Nusantoro ${ }^{1}$, Aan Awaludin ${ }^{1}$, Yendri Junaidi ${ }^{2}$, Tutik Lusyta Aulyani ${ }^{3}$ \\ ${ }^{1}$ Program Studi Produksi Ternak, Jurusan Peternakan, Politeknik Negeri Jember, Jl. Mastrip P0 BOX 164, Jember, \\ Jawa Timur, Indonesia \\ ${ }^{2}$ Program Studi Penyuluh Peternakan dan Kesejahteraan Hewan, Jurusan Peternakan, Politeknik Pembangunan \\ Pertanian Malang, Jawa Timur, Indonesia \\ ${ }^{3}$ Program Studi Budidaya Ternak, Jurusan Peternakan, Politeknik Pembangunan Pertanian Gowa, Jl. Malino KM 7, \\ Romang Lompoa, Gowa, Sulawesi Selatan, Indonesia \\ *Email Koresponden: satriabudikusuma@polije.ac.id
}

\begin{tabular}{|c|c|}
\hline ARTICLE INFO & A B S T R A K \\
\hline $\begin{array}{l}\text { Received: } \\
11 \text { February } 2021\end{array}$ & $\begin{array}{l}\text { Parasit cacing (Helminth) merupakan kendala kesehatan yang berhubungan } \\
\text { dengan investasi parasit sering dijumpai pada ayam. Penelitian ini bertujuan untuk }\end{array}$ \\
\hline Accepted: & mengidentifikasi keragaman parasit cacing yang terdapat pada ayam kampung di \\
\hline 28 March 2021 & Kabupaten Jember. Prosedur pengambilan sampel ekskreta ayam kampung dilakukan \\
\hline $\begin{array}{l}\text { Published: } \\
31 \text { March } 2021\end{array}$ & $\begin{array}{l}\text { secara acak. Sampel ekskreta yang diambil sebanyak } 150 \text { sampel di Kabupaten Jember. } \\
\text { Identifikasi keragaman spesies cacing dilakukan melalui pemeriksaan telur cacing } \\
\text { pada sampel ekskreta dengan metode sedimentasi yang dilakukan di BBVet (Balai }\end{array}$ \\
\hline \multirow{5}{*}{$\begin{array}{l}\text { Kata kunci: } \\
\text { Ayam kampung } \\
\text { Helmintiasis } \\
\text { Jember }\end{array}$} & Besar Veteriner) Wates, Yogyakarta. Parasit cacing yang teridentifikasi pada sampel \\
\hline & Capillaria sp. $(24,67 \%)$; Heterakis sp. $(10,67 \%)$; Strongyloides sp. $(3,33 \%)$; dan \\
\hline & Ascaridia sp. $(2,67 \%)$. \\
\hline & A B S T R A C T \\
\hline & $\begin{array}{l}\text { Parasitic worms (Helminths) are the one of health problems related to the parasite } \\
\text { investment that is often found in native chickens. This study aimed to identify the } \\
\text { diversity of worm parasites found in native chickens in Jember Regency. The sampling } \\
\text { procedure for native chicken excreta was carried out randomly. The excreta samples } \\
\text { taken were } 150 \text { samples around Jember Regency. Identification of the diversity of } \\
\text { worm species was carried out by examining worm eggs in excreta samples using the }\end{array}$ \\
\hline Key words: & sedimentation method at BBVet (Balai Besar Veterinary) Wates, Yogyakarta. The \\
\hline Native chicken & parasitic worms identified in the excreta samples of native chickens were worms from \\
\hline Helminthiasis & the Nematode class consisting of Capillaria sp. (24.67\%); Heterakis sp. (10.67\%); \\
\hline Jember & Strongyloides sp. (3.33\%); and Ascaridia sp. (2.67\%). \\
\hline
\end{tabular}

\section{PENDAHULUAN}

Seiring dengan pertambahan jumlah penduduk di Indonesia, kebutuhan pemenuhan protein hewani juga meningkat. Produk turunan asal ayam adalah satu di antara produk pangan hewani yang dikonsumsi dalam jumlah paling besar baik bagi kebutuhan industri maupun rumah tangga. Menurut Sulastri dan Hamdani (2018) performa produksi ternak sangat dipengaruhi oleh genetik, lingkungan, dan interaksi antara keduanya. Faktor lingkungan masih menjadi faktor yang memberikan kontribusi besar terhadap performa produksi maupun reproduksi ternak tidak terkecuali pada ternak unggas. Faktor lingkungan yang dimaksud antara lain pakan yang diberikan, manajemen pemeliharaan, dan kesehatan ternak. 
Salah satu gangguan kesehatan atau penyakit yang menyerang ayam adalah infestasi endoparasit, khususnya helminthiasis atau kecacingan. Endoparasit adalah parasit yang hidup dan makan di dalam hewan inang. Infestasi berat dapat menyebabkan buruknya efisiensi pakan, pertumbuhan, penurunan produksi telur, bahkan kematian. Unggas yang terinfeksi helminthiasis juga lebih rentan terhadap berbagai penyakit dan stres (Slimane, 2016). Helminthiasis pada ayam berdampak negatif karena mampu menurunkan efisiensi pakan, bobot ayam tidak bertambah sementara konsumsi pakan tetap. Kondisi semacam ini akan bermuara pada penurunan pada bobot panen dan produktivitas telur. Menurut Elenwo dan Elenwo (2014) hal ini tentu menyebabkan pemborosan biaya pakan yang pada akhirnya akan menyebabkan kerugian secara ekonomi.

Kejadian infeksi akibat infestasi parasit cacing dipengaruhi oleh berbagai faktor, salah satunya adalah lingkungan yang tercemar oleh telur atau larva cacing stadium infektif. Kejadian cacingan pada ayam sangat dipengaruhi oleh lokasi geografis dan iklim serta musim di sepanjang tahun. Cacing yang berparasit pada ayam menurut morfologinya dibagi menjadi tiga kelas yaitu Nematoda, Cestoda, dan Trematoda yang mempunyai siklus hidup berbeda (Thienpont et al., 2003). Keberadaan cacing dalam jumlah sedikit mampu ditoleransi oleh unggas, namun dalam jumlah tertentu cacing akan merugikan kesehatan unggas karena dapat mengambil nutrisi, menimbulkan kerusakan ekstensif pada mukosa usus dan mengganggu proses penyerapan nutrien pakan. Helminthiasis pada ayam menyebabkan kerugian secara ekonomi sehingga perlu perhatian khusus dalam penanganannya (Yazwinski et al., 2013).

Kabupaten Jember secara geografis terletak diantara $113^{\circ} 15^{\prime} 47^{\prime \prime} \mathrm{s} / \mathrm{d} 114^{0} 02^{\prime} 35^{\prime \prime}$ Bujur Timur dan diantara $7^{0} 58^{\prime} 06^{\prime \prime}$ s/d $8^{0} 33^{\prime} 44^{\prime \prime}$ Lintang Selatan. Kabupaten Jember merupakan bagian dari Provinsi Jawa Timur yang terletak kurang lebih $200 \mathrm{~km}$ ke arah Timur dari Surabaya. Sebagaian besar kawasan Kabupaten Jember merupakan Kawasan hijau yang terdiri dari hutan, sawah, tegal, dan perkebunan (BPS., 2020). Pemeliharaan ayam kampung di Kabupaten Jember terutama di peternakan rakyat masih dilakukan secara tradisional. Sistem pemeliharaan tradisional memiliki beberapa kendala, yaitu sistem manajemen perkandangan dan pemeliharaan yang cenderung kurang memerhatikan sanitasi kandang.

Permasalahan yang kerap timbul akibat kurang diperhatikannya sanitasi kandang yaitu kesehatan hewan yang menyebabkan produktivitas ayam kampung tidak akan optimal. Salah satu permasalahan kesehatan hewan yang sering dijumpai dan kurang disadari oleh peternak adalah infestasi parasit cacing atau Helminthiasis. Penelitian tentang Helminthiasis sangat diperlukan untuk mengidentifikasi dan mengevaluasi pencegahan serta penanganan Helminthiasis yang dilakukan di peternakan ayam kampung agar tercapai suatu metode yang tepat dalam mengurangi kasus Helminthiasis pada ayam kampung.

\section{MATERI DAN METODE}

Pengambilan sampel dilakukan pada bulan Juli 2020. Sampel diambil secara acak dari ayam kampung di beberapa kecamatan di Kabupaten Jember. Sampel berupa ekskreta ayam kampung yang baru didefekasikan. Ekskreta atau kotoran ayam merupakan campuran feses, urin, dan sisa hasil metabolisme yang berasal dari pakan yang tidak tercerna di dalam saluran pencernaan.

Jumlah sampel ekskreta yang diambil sebanyak 150 sampel. Masing-masing sampel kurang lebih 5 gram. Ekskreta dimasukkan ke dalam pot plastik sampel dan dicampur dengan 2-3 tetes formalin 10\% kemudian diberi label. Identifikasi keragaman spesies telur cacing dengan melakukan pemeriksaan telur cacing yang terdapat pada sampel ekskreta ayam menggunakan metode sedimentasi yang dilakukan di Balai Besar Veteriner (BBVet) Wates.

\section{Metode Sedimentasi}

Sampel ekskreta diambil sebanyak 3 gram kemudian dimasukkan ke dalam beaker glass 100 $\mathrm{ml}$ dan ditambah dengan akuades hingga $50 \mathrm{ml}$ kemudian diaduk sampai ekskreta hancur dan homogen. Larutan ekskreta yang sudah homogen diambil dengan menggunakan pipet dan dimasukkan ke dalam tabung sentrifuse sampai $2 / 3$ tabung. Sentrifugasi dilakukan dengan kecepatan 2000 rpm selama 5 menit (Awaludin et al., 2018). 
Supernatan dibuang kemudian endapan ditambah dengan akuades sampai $2 / 3$ tabung dan dilakukan sentrifugasi kembali dengan kecepatan 2000 rpm selama 5 menit. Pengendapan ini dilakukan hingga supernatan kelihatan jernih kemudian supernatan dibuang, endapan (sedimen) yang terbentuk diambil dengan pipet dan diletakkan di atas object glass, ditambahkan zat warna (larutan eosin 1\%) kemudian ditutup dengan deck glass. Pengamatan dilakukan dengan mikroskop pada perbesaran 10x10 untuk melakukan identifikasi telur cacing yang ditemukan (Awaludin et al., 2018). Data yang didapatkan kemudian dianalisis secara deskriptif dengan dibandingkan literatur yang relevan.

\section{Rumus Nilai Prevalensi}

Nilai prevalensi Helminthiasis dihitung dengan rumus menurut (Jaiswal et al., 2020) sebagai berikut: Nilai Prevalensi = Jumlah sampel terinfeksi/Jumlah sampel yang diuji x 100\%

\section{HASIL DAN PEMBAHASAN}

Hasil pemeriksaan dan identifikasi telur cacing pada sampel ekskreta ayam kampung di Kabupaten Jember terlihat adanya sebaran berbagai spesies parasit cacing. Sebaran spesies parasit cacing pada ayam kampung yaitu sebanyak 48 sampel positif (32\%) teridentifikasi adanya parasit cacing (Tabel 1.).

Parasit cacing yang teridentifikasi pada ayam kampung di Kabupaten Jember terdiri dari kelas Nematoda, yang terdiri dari Capillaria sp. (24,67\%), Heterakis sp. $(10,67 \%)$, Strongyloides sp. (3,33\%), dan Ascaridia sp. (2,67\%). Telur cacing yang ditemukan pada sampel ekskreta ayam kampung tersebut diduga disebabkan manajemen pemeliharaan ayam kampung yang cenderung diumbar sehingga siklus hidup parasit cacing akan terus berjalan dan menyebar ke ayam kampung lainnya. Semakin tinggi nilai prevalensi Helminthiasis menunjukkan bahwa semakin rendah manajemen pengendalian penyakit yang diterapkan pada suatu peternakan tersebut. Seperti dilaporkan oleh (Sarba et al., 2019) bahwa parasit gastrointestinal tersebar luas di dunia termasuk di Ethiopia. Pemeriksaan parasitologis menunjukkan adanya tiga spesies Nematoda dan lima spesies Cestoda. Ascaridia galli (69,8\%) dan Heterakis gallinarum (13,5\%) adalah
Tabel 1. Hasil identifikasi telur cacing pada ternak ayam kampung di Kabupaten Jember

\begin{tabular}{|c|c|c|c|c|}
\hline \multirow{2}{*}{ No. } & \multicolumn{2}{|c|}{ n (ayam) } & \multirow{2}{*}{$\begin{array}{l}\text { Prevalensi } \\
(\%)\end{array}$} & \multirow[t]{2}{*}{ Jenis telur cacing } \\
\hline & Total & infeksi & & \\
\hline 1 & 150 & 1 & 0,67 & Ascaridia sp. \\
\hline 2 & & 2 & 1,33 & $\begin{array}{l}\text { Ascaridia sp., } \\
\text { Capillaria sp. }\end{array}$ \\
\hline 3 & & 27 & 18 & Capillaria sp. \\
\hline 4 & & 4 & 2,67 & Heterakis sp. \\
\hline 5 & & 8 & 5,33 & $\begin{array}{l}\text { Heterakis sp., } \\
\text { Capillaria sp. }\end{array}$ \\
\hline 6 & & 1 & 0,67 & $\begin{array}{l}\text { Heterakis sp., } \\
\text { Ascaridia sp. }\end{array}$ \\
\hline 7 & & 3 & 2 & $\begin{array}{l}\text { Heterakis sp., Stron- } \\
\text { gyloides sp. }\end{array}$ \\
\hline 8 & & 102 & 68 & Negatif \\
\hline 9 & & 2 & 1,33 & Strongyloides sp. \\
\hline
\end{tabular}

spesies Nematoda dominan kemudian Railletina tetragona $(54,0 \%)$ dan Railletina echinobothrida $(46,8 \%)$ adalah spesies yang paling umum teridentifikasi dari kelas Cestoda.

Telur cacing kelas Nematoda merupakan satu-satunya parasit cacing yang teridentifikasi pada ayam kampung di Kabupaten Jember. Parasit cacing dewasa dari kelas Nematoda tersebut merupakan cacing yang berparasit pada saluran gastrointestinal khususnya pada bagian usus halus. Parasit cacing dari kelas Nematoda ini dalam siklus hidupnya tidak memerlukan host reservoir, sehingga siklus hidup parasit ini lebih sederhana sehingga sangat mudah penyebarannya dalam menginfeksi dan berinfestasi pada ternak (Levine, 1990). Nematoda termasuk dalam filum Nemathelminthes, kelas Nematoda. Nematoda unggas bersifat parasit, dan cacing tidak tersegmentasi. Bentuknya biasanya silindris dan memanjang, tetapi kutikula bisa melingkar annulasi, halus, memiliki garis-garis membujur atau ornamen berupa duri kutikular (Belete et al., 2016). Infestasi parasit cacing kelas Nematoda juga ditemukan pada peternakan ayam petelur umbaran (Sherwin et al., 2013). Tingginya frekuensi kehadiran parasit cacing dari kelas Nematoda khususnya Ascaridia galli dan Strongyloides sp. pada ayam buras karena cacing ini dapat bertahan di tempat yang lembap. Faktor cuaca seperti temperatur dan kelembapan yang sesuai dengan kehidupan cacing serta manajemen 
atau cara pemeliharaan dan pemberian pakan yang kurang baik dapat mendukung terjadinya infeksi cacingan (Pradana et al., 2015).

Telur cacing dapat diidentifikasi dengan melihat bentuk morfologi telur cacing. Parasit cacing kelas Nematoda pada ayam kampung di Kabupaten Jember terdiri dari beberapa spesies. Pada spesies Capillaria sp. memiliki telur dengan karakteristik termasuk ke dalam telur cacing berukuran kecil, berbentuk lemon, memiliki ukuran panjang 45-50 $\mu \mathrm{m}$, lebar 22$25 \mu \mathrm{m}$, mempunyai sumbat kutub (polar plugs) yang sedikit menonjol, memiliki cangkang tebal dengan permukaan berkerut, tidak bersegmen (unsegmented), granular. Spesies Strongyloides sp. memiliki telur dengan karakteristik yang termasuk dalam telur cacing berukuran sedang, memiliki ukuran telur dengan panjang 47-65 $\mu \mathrm{m}$, lebar 25-26 $\mu \mathrm{m}$, berbentuk ellips lebar, berdinding tipis, tidak mempunyai warna, cangkang chitinous dengan permukaan halus, berembrio (Thienpont et al., 2003).

Spesies Ascaridia sp. menyebabkan pertumbuhan terhambat, produktivitas rendah, iritasi dan radang mukosa sehingga mengganggu penyerapan makanan (Uhuo et al., 2013). Ascaridia sp. memiliki ukuran telur sedang dengan panjang 75- $80 \mu \mathrm{m}$, lebar $45-50 \mu \mathrm{m}$, berbentuk elips, dinding samping agak berbentuk tabung, cangkang 3 lapis yang tebal dan halus dengan lapisan tengah paling berkembang, konten tidak tersegmentasi, dibedakan dari telur Heterakis sp. yang ukurannya lebih kecil dan dinding sampingnya halus. Spesies Heterakis sp. memiliki ukuran telur sedang dengan panjang 63-75 $\mu \mathrm{m}$, lebar 36 - $48 \mu \mathrm{m}$, berbentuk elips dengan dinding samping yang halus, tebal dan cangkang yang halus, konten tidak tersegmentasi, berbeda dari telur Ascaridia sp. yang ukurannya lebih besar dan bentuk dinding sampingnya agak seperti tabung (Thienpont et al., 2003).

Infeksi Nematoda menyebabkan penurunan laju pertumbuhan dan penurunan berat badan terkait dengan kerusakan mukosa usus yang disertai dengan kerusakan dinding usus, kehilangan darah dan infeksi sekunder yang menyebabkan penurunan berat badan dan produksi yang rendah. Umumnya Nematoda secara signifikan mempengaruhi kesehatan ayam dengan berbagi pakan yang dikonsumsi oleh inang, pada ayam akan menghambat pertumbuhan dan mengurangi produksi telur dan daging (Slimane.,
2016).

Terdapat enam puluh delapan persen dari populasi penelitian yang menunjukkan hasil negatif atau tidak ditemukannya telur cacing pada ekskreta ayam kampung tersebut. Hal tersebut dapat disebabkan karena periode pengambilan sampel pada bulan Juli, yang diketahui bertepatan pada musim kemarau. Masih ditemukannya kasus Helminthiasis pada peternakan ayam kampung di Kabupaten Jember mengindikasikan bahwa sanitasi lingkungan kandang dan upaya pengendalian penyakit yang belum optimal. Menurut Kementan (2014) iklim tropis dan kelembaban yang tinggi memberikan kondisi yang menguntungkan bagi perkembangan telur cacing dan ketahanan hidup larva dan telur infektif di alam. Terdapat korelasi positif antara populasi cacing Ascaridia galli pada ayam dengan suhu, curah hujan dan kelembaban. Umumnya jumlah cacing lebih banyak pada musim hujan karena telur dapat berkembang pada lingkungan yang lembab, khususnya pada unggas yang tidak dikandangkan kemungkinan tertular cacing Ascaris lebih besar.

Prevalensi Helminthiasis yang ditunjukkan pada Tabel 1 didominasi oleh cacing kelas Nematoda. Pada penelitian sejenis terdapat pula jenis cacing dari kelas lain seperti Cestoda. Nilai prevalensi pada penelitian ini masih lebih rendah jika dibandingkan dengan nilai prevalensi Helminthiasis pada penelitian El Dakhly et al., (2018) yaitu mencapai 55,79\%. Semakin tinggi nilai prevalensi Helminthiasis menunjukkan bahwa semakin rendah tindakan pengendalian penyakit yang dilakukan oleh suatu peternakan tersebut.

Hasil pemeriksaan menggunakan metode sedimentasi dan apung oleh Damayanti et al. (2019) menunjukkan jenis cacing saluran pencernaan yang menginfeksi ayam buras di Desa Kramatyaitu terdiri dari cacing kelas Cestoda yaitu Hymenolepis sp., Railletina sp. sedangkan dari kelas Nematoda yaitu Capillaria sp., dan Heterakis gallinarum. Infestasi parasit cacing pada ayam kampung didominasi oleh cacing Nematoda dan Cestoda (El Seify et al., 2017). Terdapat hubungan erat antara terjadinya Helminthiasis dengan umur ayam yaitu prevalensi tinggi lebih banyak ditemukan pada ayam dewasa daripada ayam muda (El Dakhly et al., 2018). Molla et al. (2012) melaporkan setidaknya ada tiga jenis infestasi Helminthiasis oleh Nematoda dan tujuh jenis dari 
Cestoda pada ayam kampung. Tingginya angka prevalensi infestasi parasit cacing Nematoda dan Cestoda pada ayam kampung menuntut adanya tindakan preventif dan metode pengendalian yang sesuai (Berhe et al. (2019); Shiferaw et al. (2016); Cherinet (2019)). Prevalensi cacing gastrointestinal yang tinggi pada ayam kampung kemungkinan disebabkan oleh rendahnya tingkat manajemen dan pelayanan kesehatan (Belete dan Addis, 2015).

Terbatasnya keberagaman telur cacing yang teramati dapat disebabkan oleh tidak teridentifikasinya telur cacing karena sudah memasuki fase larva. Pengamatan lebih lanjut perlu dilakukan dengan menggunakan metode nekropsi untuk mengamati saluran pencernaan ayam tersebut. Pemeriksaan dengan metode nekropsi yaitu pemeriksaan patologis pada objek hewan yang telah mati dengan cara pembedahan dan pengamatan langsung pada organ atau bagian tubuh tertentu hewan tersebut (Zannah et al., 2020).

Besar kemungkinan pada bagian intestin dan sekum terdapat larva cacing yang lebih beragam jika dilakukan nekropsi pada sampel ayam kampung yang diteliti. Siklus perkembangan Nematoda dijelaskan oleh (Belete et al., 2016), contohnya pada siklus hidup Ascaridia galli dapat bersifat langsung dalam inang tunggal, melibatkan dua populasi utama, yaitu parasit yang dewasa secara seksual di saluran pencernaan dan tahap infektif yaitu larva 3 (L3). Larva tidak menetas tetapi berkembang di dalam telur sampai mencapai tahap L3 yang membutuhkan waktu tujuh sampai empat belas hari, tergantung pada faktor lain seperti kondisi cuaca. Siklus hidup selesai saat telur infektif tertelan oleh inang baru melalui air atau pakan yang terkontaminasi. Telurtelur yang mengandung larva 3 secara mekanis diangkut ke duodenum. Telur infektif tertelan oleh ayam hingga mencapai proventrikulus dan menetas. Suhu, tingkat karbon dioksida, dan nilai $\mathrm{pH}$ dianggap sebagai faktor pemicu yang memberi tanda pada larva untuk menetas dari telurnya. Larva kemudian menggali lubang lapisan mukosa usus halus sebagai tempat berkembang, kemudian masuk kembali ke usus halus dan berkembang menjadi dewasa dengan memakan isi usus. Jika hewan itu mampu meningkatkan kekebalan respon terhadap larva, yaitu dari sebelum terpapar, larva tidak berkembang menjadi dewasa tetapi bersembunyi di mukosa usus halus. Hal ini umum terjadi pada ayam yang lebih tua. Inang perantara seperti cacing tanah diperkirakan berperan dalam penularan Ascaridia galli sehingga ayam kampung cenderung memiliki risiko infeksi yang lebih tinggi.

Banyak faktor yang dapat meningkatkan prevalensi Helminthiasis pada suatu peternakan ayam antara lain manajemen pemeliharaan, lokasi peternakan dan sumber infeksi. Oleh karena itu, Slimane (2016) berpendapat bahwa tindakan tegas harus dilakukan untuk mengendalikan parasit yang penting secara ekonomi ini. Usaha untuk memperbaiki sistem pemeliharaan, sanitasi kandang (Dakpogan et al., 2019), lingkungan yang higienis (Jaiswal et al. 2020) menjaga kebersihan tempat pakan dan minum serta pemberian anthelmintik dan dosis yang tepat pada peternakan ayam kampung perlu dilakukan dengan baik dan benar agar prevalensi Helminthiasis dapat ditekan (Iboh, (2019); Uhuo et al., (2013)). Dampak positif dari rendahnya prevalensi Helminthiasis nantinya dapat dirasakan oleh peternak, yaitu memperoleh keuntungan yang optimal. Salam (2015) memaparkan bahwa dalam kebanyakan kasus, tingkat keparahan perubahan patologis akibat Helminthiasis tergantung pada derajat infeksi parasit selain potensi patogen dari parasit.

\section{KESIMPULAN}

Parasit cacing yang teridentifikasi pada ayam kampung di Kabupaten Jember merupakan cacing dari kelas Nematoda yang terdiri dari Capillaria sp. (24,67\%); Heterakis sp. (10,67\%); Strongyloides sp. (3,33\%); dan Ascaridia sp. $(2,67 \%)$. Penelitian tentang derajat infeksi pada setiap parasit cacing perlu dilakukan untuk mengetahui tingkat keparahan infestasi cacing. Upaya yang dapat dilakukan untuk menekan timbulnya kasus Helminthiasis pada peternakan ayam kampung di Jember diantaranya adalah memperbaiki sistem pemeliharaan, menjaga sanitasi kandang, kebersihan tempat pakan dan minum, serta pemberian anthelmintik yang terprogram dengan baik dan benar.

\section{UCAPAN TERIMA KASIH}

Tim peneliti berterima kasih kepada P3M Politeknik Negeri Jember yang telah mendanai 
kegiatan penelitian ini melalui sumber dana PNBP 2020.

\section{DAFTAR PUSTAKA}

Awaludin, Aan, Nurkholis, and Suluh Nusantoro. 2018. "Identify the Diversity of Helminth Parasites in Cattle in Jember District (East Java - Indonesia)." in 1st International Conference on Food and Agriculture. IOP Conference Series: Earth and Environmental Science. Vol. 207. Bali: IOP Publishing.

Belete, Abebe, and Mekonnen Addis. 2015. "A Survey of Gastrointestinal Helminthes among Chickens in Bahir Dar Town, Ethiopia." European Journal of Applied Sciences 7(2):64-71.

Belete, Abebe, Mekonnen Addis, and Mihretu Ayele. 2016. "Review on Major Gastrointestinal Parasites That Affect Chickens." Journal of Biology, Agriculture and Healthcare 6(11):11-21.

Berhe, Mebrahtu, Berhanu Mekibib, Abrha Bsrat, and Gebretsadik Atsbaha. 2019. "Gastrointestinal Helminth Parasites of Chicken under Different Management System in Mekelle Town, Tigray Region, Ethiopia." Journal of Veterinary Medicine 2019.

BPS, Badan Pusat Statistik. 2020. Kabupaten Jember Dalam Angka 2020. Jember: Badan Pusat Statistik Kabupaten Jember.

Cherinet,Yoseph.2019."BurdenofGastrointestinal Helminths in Backyard Local Chickens in Selected Sites in East Shoa Zone, Oromia, Ethiopia." Journal of Veterinary Medicine and Allied Science 3(3):2019.

El Dakhly, Khaled Mohamed, Mahmoud A. El Seify, Eman Sayed Mohammed, and Ismail Saad Elshahawy. 2018. "Prevalence and Distribution Pattern of Intestinal Helminths in Chicken and Pigeons in Aswan, Upper Egypt." Tropical Animal Health and Production.

Dakpogan, Hervé Brice, Venant Pascal Houndonougbo, Serge Mensah, Toussaint Hagbe, Grégoire Tchodo, Armand Bienvenu Gbangboche, Frédéric Houndonougbo, and Christophe Chrysostome. 2019. "Chicken Gastrointestinal Nematode and Coccidia Prevalence in Abomey-Calavi District, Benin." International Journal of Biosciences 6655:363-69.

Elenwo, A. C., and E. J. Okafor-Elenwo. 2014. "Production Losses Associated with GastroIntestinal Helminthiasis in Egg-Laying Domestic-Fowl (Gallus Gallus Domesticus:
Galliformes) in Poultry Farms in Parts of Rivers State, Nigeria." Journal of Natural Sciences Research 4(1):14-19.

Iboh, Cletus Inah. 2019. "Investigation of Gastrointestinal Parasites of Local Chickens (Gallus Domesticus) in Ugep, Yakurr Local Government Area, Cross River State, Nigeria." South Asian Journal of Parasitology 2(3):1-5.

Jaiswal, Kamal, Suman Mishra, and Anjum Bee. 2020. "Prevalence of Gastrointestinal Helminth Parasites in Gallus Gallus Domesticus in Lucknow, U. P, India." Advances in Zoology and Botany 8(5):42230.

Kementan, Kementerian Pertanian. 2014. Manual Penyakit Unggas. 2nd ed. Jakarta.

Levine, Norman D. 1990. Buku Pelajaran Parasitologi Veteriner. Yogyakarta: Gadjah Mada University Press.

Molla, W., H. Haile, G. Almaw, and W. Temesgen. 2012. "Gastrointestinal Helminths of Local Backyard Chickens in North Gondar Administrative Zone , Ethiopia." Revue de Medecine Veterinaire 163(7):362-67.

Pradana, David Putra, Tjipto Haryono, and Reni Ambarwati. 2015. "Identifikasi Cacing Endoparasit Pada Feses Ayam Pedaging Dan Ayam Petelur." Lentera Berkala Ilmiah Biologi.

Salam, S. .. $\quad$ T. 2015. "Gastro-Intestinal Helminthiasis: An Unseen Threat To the Backyard Poultry Production of Kashmir Valley." Internation Journal of Science and Nature 6(1):63-69.

Sarba, Edilu Jorga, Morka Dandecha Bayu, Endrias Zewdu Gebremedhin, Ketema Motuma, Samson Leta, Kebede Abdisa, Getachew Kebebew, and Bizunesh Mideksa Borena. 2019. "Veterinary Parasitology: Regional Studies and Reports Gastrointestinal Helminths of Backyard Chickens in Selected Areas of West Shoa Zone Central , Ethiopia." Veterinary Parasitology: Regional Studies and Reports 15(April 2018):100265.

El Seify, Mahmoud A., Khaled Mohamed El Dakhly, and Eman Sayed. 2017. "Studies On Parasitic Helminths of Domestic Birds in Aswan Governorate." Kafrelsheikh Veterinary Medical Journal 15(1):43-64.

Sherwin, C. M., M. A. F. Nasr, E. Gale, M. Patek, K. Stafford, M. Turp, and G. C. Coles. 2013. "Prevalence of Nematode Infection and Faecal Egg Counts in Free-Range Laying Hens: Relations to Housing and Husbandry." British Poultry Science 54(1):12-23.

Shiferaw, Solomon, Firaol Tamiru, Askale Gizaw, Dagmawit Atalel, Waktole Terfa, Morka 
Dandecha, and Abreham Mekibib. 2016. "Study on Prevalence of Helminthes of Local Backyard and Exotic Chickens in and Around Ambowest Shoa Zone, Oromia Regional State, Ethiopia." Journal of Veterinary Medical Science 4(2):2-5.

Slimane, Badreddine Ben. 2016. "Prevalence of the Gastro-Intestinal Parasites of Domestic Chicken Gallus Domesticus Linnaeus, 1758 in Tunisia According to the Agro-Ecological Zones." Journal of Parasitic Diseases 40(3):774-78.

Sulastri, and Muhammad Dima Iqbal Hamdani. 2018. Dasar Pemuliaan Ternak. Bandar Lampung: Aura.

Thienpont, D., Frans Rochette, and O. F. J. Vanparijs. 2003. Diagnosing Helminthiasis by Coprological Examination. 3rd ed. Beerse, Belgium: Janssen Animal Health.

Uhuo, A. C., F. C. Okafor, O. O. Odikamnoro, C. S. Onwe, M. C. Abarike, and J. .. Elom. 2013. "Common Gastrointestinal Parasites of Local Chicken (Gallus Domesticus) Slaughtered in Some Selected Eatery Centres in Abakaliki, Ebonyi State: Implication for Meat Qualit." International Journal of Development and Sustainability 2(2):1416-22.
Yazwinski, T., C. Tucker, E. Wray, L. Jones, Z. Johnson, S. Steinlage, and J. Bridges. 2013. "A Survey on the Incidence and Magnitude of Intestinal Helminthiasis in Broiler Breeders Originating from the Southeastern United States." Journal of Applied Poultry Research 942-47.

Zannah, Miftakhul, Aan Awaludin, Dyah Laksito Rukmi, Suluh Nusantoro, and Satria Budi Kusuma. 2020. "Case Study on Genesis Infectious Bursal Disease (IBD) on Broiler Chickens at PT. Aretha Nusantara Farm Bandung." Journal of Livestock Science and Production 4(1):224-30. 